\title{
A Review Article of the Pragmatics-Based-Curriculum in EFL Context: Focus on the Curriculum in Iraq
}

\author{
Ahmed Ibrahim 1 , Mahendran Maniam² \\ ${ }^{1,2}$ University Pendidikan Sultan Idris (UPSI, Malaysia \\ Email: lailynurlina@ump.ac.id
}

\section{Abstract}

The benefit of studying language through pragmatics is that the people can realize the other's meaning and the important disadvantage is that analyzing the peoples' concepts is hard objectively. The study of pragmatics is interesting as it studies how people make sense of each other linguistically, in the same time, it can be a disappointed area of study because it needs us to make sense of people and what they have in mind. According to Bardovi-Harlig (1991), the real responsibility of the classroom teacher is making students more aware about existing pragmatic functions in language, especially in discourse. The teachers should know about these speech acts and their elements to use the natural input for the students in a particular content, for a particular purpose, and as part of a strategy. Accordingly, the current review article aims at revealing the following; first, is pragmatics important in teaching and learning a second and foreign languages, based on this, is it a part of teaching English? Second, to show to what extent pragmatics is included in the EFL curriculums, textbooks more specifically?
Keywords

Pragmatics; EFL classrooms; curriculum; EFL context

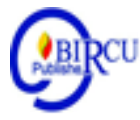

\section{Introduction}

Using language appropriately does not mean mere correct phonology, morphology, syntax, and semantics, but involves pragmatic knowledge or, to be more specific, cultural knowledge to avoid misunderstandings or communication breakdowns. Misunderstandings caused by grammatical mistakes are more tolerated than those rooted in different assumptions (Hyde, 1998). This raises an issue at the language pedagogy level, which is more than grammatical or structural accuracy. (Vu, 2017, p.1). Barron, (2003); Hymes, (1972); Widdowson, (1992), argued that "with the rapid economic development and further implementation of the reform and opening policy, the role of English, especially communicative competence in English, which refers to both the knowledge of a language and the ability to use that knowledge in social interactions, has become more and more important in the daily life of people around the world in general and in Iraq in specific. Since a language is a process of producing utterances, it is, therefore, should be studies under the umbrella of communicative competence as a branch of linguistics called pragmatics".

\section{Review of Literature}

\subsection{What is Pragmatics?}

The term 'pragmatics' is attributable to the philosopher of language, Charles Morris (1938), who defined pragmatics as "the science of the relations of signs to their interpreters" and located it within semiotics, a science of signs (p. 30). A number of definitions of 'pragmatics' offered by different linguists and researchers (Crystal, 1997; Ferrara, 1985; 
Leech, 1983; Levinson, 1983; Mey, 1993; Verschueren, 1999; Yule, 1996) who viewed pragmatics from different perspectives and contexts. The main reasons for the diverse definitions are: (a) the field of pragmatics is, itself, a varied discipline of study, which embraces different aspects of the relationship between meaning and context; and (b) the different models and theories from which pragmatics derives have divergent concepts of what are the suitable terms of the discussion (Chapman, 2011). Pragmatics is "the study of language use" (Levinson, 1983, p. 5; Verschueren, 1999, p. 1). This is probably the simplest and least controversial definition. It describes the nature of pragmatics and serves as a starting point in discussion of pragmatics. However, it does not provide ample theoretical bases for more complicated treatment of pragmatics. The criticism has led to a number of more complex definitions of pragmatics. Leech (1983) redefined pragmatics for the purposes of linguistics as "the study of meaning in relation to speech situations" (p. 6). Leech (1983) and Thomas (1983) divided pragmatics into pragmalinguistics and sociopragmatics. Pragmalinguistics is "the study of the more linguistic end of pragmatics" (Leech, 1983, p. 11). According to him, pragmalinguistics is related to grammar and refers to the particular resources a speaker has to convey particular communicative acts and interpersonal meanings. Sociopragmatics is "the sociological interface of pragmatics" (Leech, 1983, p. 10). Sociopragmatics is related to sociology and is concerned with the social conditions under which speakers interpret and perform their communicative acts (Leech, 1983). According to Thomas (1983), pragmalinguistics refers to linguistic forms and functions, whereas sociopragmatics is related to appropriate social behaviours. This dichotomy of pragmalinguistics versus sociopragmatics is important as it looks at language use at two levels: how to use language grammatically correctly and how to use it socially appropriately.

\section{Discussion}

\subsection{The Importance of Teaching Pragmatics in EFL/ESL Classrooms}

This section focused mainly on reviewing the studies that discussed the importance of pragmatics in developing second and foreign language. Arghashi and Gorjian (2018) investigated the effectiveness of pragmatic functions instruction on Iranian high school EFL learners' writing proficiency. Sixty female Iranian learners studying at the first grade of high school in Dezfool were selected through simple random sampling procedure. They were divided into experimental and control groups. The control group was taught based on usual and traditional methods of writing instruction and the experimental group received treatment based on pragmatic function instruction in writing one-paragraph essays. Results revealed that there was a significant difference between the mean scores of the participants in the control and experimental groups ( $p>0.05)$. Thus the students who receive explicit pragmatics instruction focusing on language pragmatics functions in writing essay performed better on the post-test than those who did not. Like others, Koran and Koran (2017) aimed at reviewed the most widely used techniques to teach pragmatic competence in an EFL classroom as well as provide theoretical background for the concept and closely related notions such as speech acts and politeness strategies. They highlighted the importance of teaching pragmatic competence as a vital part of language teaching curriculum. This probably was the result of generations of learners of English language who completed their studies in the foreign language with a relatively good general language proficiency but weaker skills to interpret the messages and intentions that are conveyed in conversations, correctly. This particular competence is referred to as pragmatic competence. Findings showed that pragmatic 
competence should be developed through explicit and implicit instruction, with the prevalence of the former, with a range of activities and situations/contexts. Especially the rules of social norms that are different from the ones in the learners' native cultures should be given emphasis. After all, communication is not a mere exchange of messages, but it also is correct and appropriate interpretation of intentions on both sides and being able to respond accordingly. That is why, integrating elements of pragmatic competence in EFL curricula and lesson plans is of crucial importance.

Similarly, Shokouhi and Rezaei (2015) explored the importance of teaching pragmatics in the classrooms. In this review the speech act of complimenting is selected as the focus of teaching. Review showed that teachers should pay more attention to pragmatics and teaching it in the classroom. Lack of pragmatic knowledge may cause a failure in communication. Besides emphasizing on only grammar aspects teachers should teach the appropriate usage of language in different situations. Likewise, Al-Aghbari (2016) investigated the integrating of pragmatic competence in teaching English to the students of Medicine at Taiz University. As advocated by the results of the study, a medical drama is used as input to link the students' field with learning the language. This encouraged the students to deal with authentic language and to maintain their interest in learning English through a medical drama. Results revealed that pragmatics provided the students with opportunities to practice what they have learned. In the Iraqi EFL context, Mohammed (2012) investigated the effect of explicit instruction of pragmatics. Intended. A total of twenty EFL Iraqi students were chosen randomly to participate in the study as an experimental group. They were explicitly instructed in the pragmatics of the speech acts of requests and refusals. Another group of twenty students, were also chosen randomly to participate in the study as a control group. This group received no instruction in the pragmatics of the speech acts of requests and refusals. The results of the pre-test showed that both groups (experimental and control) were unable to produce the speech acts of requests and refusals in the same way as native speakers of English do. However, the results of the post-test showed that the experimental group (after having been explicitly instructed in the pragmatics of the speech acts of requests and refusals) generated significantly better responses than the control group.

In line with others, Locastro (2012) stated that improving the learners' pragmatic knowledge is as important as developing one's IT and technology skills. Both are important for the world of today. ESL/EFL teachers are on the frontlines of pragmatic development. They also had great responsibility for learners who intend to use the L2 for study or work abroad. So the teachers in particular need to pursue their own ability to think critically about language data and instances of use to prepare themselves. Their learners benefit from the explicit teaching of pragmatics by their teachers and ideally become autonomous learners, doing pragmatics to solve communication problems and pushing their competence level (p.308). More importantly, Brubæk (2012) investigated Norwegian EFL students' level of pragmatic competence in English as well as their understanding of politeness and their ability to demonstrate politeness in English in various contexts. Results revealed that pragmatic competence is neglected in EFL classrooms. The findings in the article were, to a large extent, supported by the results of the investigation conducted among the three teachers. They expressed insecurity in terms of teaching pragmatic competence, and indicated that other aspects of language were more important, such as grammar, reading and writing. They therefore seemed to ignore the central position that pragmatic competence and knowledge of politeness conventions is given in the English subject curriculum. In her study, Aufa (2014) investigated the efficacy of using DCT as explicit instruction in the development of pragmatic competence of EFL learners in Indonesia. She found out that it results in variations of linguistic forms that contribute to learners' developing performance growth. Accordingly, 
he advocates the effective use of DCT as one of the pragmatic teaching methods in the context of the EFL. In another study conducted by Rajabia, Azizifara, and Gowhary (2015) who explored the effect of explicit instruction of pragmatic level on appropriate performance of request speech act across two proficiency levels with regard to two social variables of status and distance. Data were collected using a Discourse Completion Test (DCT). The results revealed that explicit instruction is a facilitative tool to develop L2 learners' pragmatic competence. Moreover, it was found that L2 proficiency influence on overall appropriateness of speech acts production.

According to Rueda (2006), pragmatic studies provide the students with linguistic tools and helping them to learn and understand the action in an appropriate way, i.e., TL culture. In their study, Choraih, Loutfi, and Mansoor (2016) highlighted the importance of teaching L2 pragmatic competence in the L2 classroom. It has been shown that language proficiency should be correlated with not only grammatical knowledge, the mastering of syntax, morphology, phonology and semantics, but also with the pragmatic aspects of the target language, the lack of which may result in communication breakdown.

\subsection{Pragmatics in Curriculum}

This section reviewed the studies that focused on analyzing pragmatic content in curriculum, more specifically, in textbook. The textbook is the center of the curriculum and syllabus in most classrooms; however, rarely does it provide enough information for learners to successfully acquire pragmatic competence (Vellenga, 2004). This paper analyzed 8 English as a Second Language (ESL) and English as a Foreign Language (EFL) textbooks to determine the amount and quality of pragmatic information included. Detailed analysis focused specifically on the use of metalanguage, explicit treatment of speech acts, and metapragmatic information, including discussion(s) of register, illocutionary force, politeness, appropriacy and usage. Findings revealed that textbooks include a paucity of explicit metapragmatic information is the textbooks were rare. Implications suggest that textbook developers could include authentic examples of speech acts and sufficient metapragmatic explanations to facilitate acquisition of pragmatic competence.

The case study conducted by $\mathrm{Vu}$ (2017) aimed at of a analyzing the pragmatic content presented in textbooks and the curriculum of Vietnamese university textbooks. Data collected from questionnaire survey, interviews, focus group, classroom observations, and document analysis. Major findings include: teachers' understanding of pragmatic knowledge and its teaching varied, although all of them recognised the vital importance of teaching pragmatic knowledge in enhancing EFL students' communicative competence; the way teachers taught pragmatic knowledge was influenced by how they learned pragmatics and their perceptions of pragmatics; there was a dearth of pragmatic knowledge presented in the analysed textbook; and teachers relied mostly on textbooks to teach pragmatics and encountered difficulties in teaching pragmatics because of their lack of pragmatic competence as well as methods to teach it.

In another important study, Ji (2007) examined the pragmatic content in College English textbooks and the process of College English teaching and learning in the Chinese context. The primary aim of the study is to investigate qualitatively the nature of pragmatic information and the extent to which it is included in the textbooks and in teaching and learning in the classroom. Findings of the study argue that (I) neither College English textbooks nor College English classroom teaching provide adequate pragmatic input to learners with regards to quantity and quality of pragmatic input. (2) The extent of pragmatic knowledge in College English textbooks and classroom teaching is limited and predominantly concentrates on metapragmatic information, metalanguage, speech acts, and 
cultural information. (3) Pragmatic information in the textbooks and classroom teaching is randomly distributed. (4) The pragmatic input is taught explicitly with limited tasks and task varieties. (5) The content- or information-based approach reflecting an informationtransmission model neglects the appropriate use of the target language, essential for effective communication, and affords students with little opportunities for interactive learning and the use of English for real purposes. The findings of the study provide empirical evidence for College English textbook writing and classroom teaching and learning in an EFL context in China. The theorizing of the study as well as a proposed instructional model highlights a need for a language pedagogy that systematically incorporates pragmatics in the English curriculum for second and foreign language teaching and learning.

LoCastro (1997b) examined 17 Ministry of Education-approved textbooks of senior high school English. The purpose was to find out whether the textbooks entailed the resources of politeness and helped students develop their pragmatic competence to carry out linguistic etiquette. Several features which are formal, linguistic markers of politeness drawn from Lakoff (1972), Carrell and Konneker (1981), and Blum-Kulka et al. (1989) were used as a baseline for the textbook analysis (Lexical: please, gladly, be happy to, etc., forms of address; syntactic/semantic: tags, negation, sentence type, modals, and tense). The author argued that there is a noticeable absence of politeness in the textbooks and suggested five possible explanations for the absence of politeness, hence hoping to raise the teachers' awareness of politeness of pragmatic competence. This study used data exclusively collected in Japan. The analysed textbooks were EFL textbooks for senior high school English learners in Japan. Quantitative data were analysed and only one aspect of pragmatic knowledge (politeness) was explored.

Kim and Hall (2002) explored the use of this approach to facilitating the development of native Korean-speaking children's pragmatic competence in English. Four native-Koreanspeaking children who were learning EFL took part in the study. Seven books describing the context of school in the United States written by Miriam Cohen were chosen to be used in the study. Kim and the children engaged in interactive book reading sessions over four months for a total of 35 sessions. The findings showed that children's participation in the interactive book reading program led to significant changes in the mean number of words, utterances, and talk management features. The authors concluded that book-based programs should be particularly useful in the teaching of pragmatic competence specific to those contexts with which they may have had little experience. By using books and role play to help to create these contexts in the classroom, these teachers can provide access to pragmatic knowledge and skills in the target language to which both the learners and the teachers may not otherwise be exposed" (Kim \& Hall, 2002, p. 345).

\section{Conclusion}

In can be concluding that section one revealed that researchers; Arghashi and Gorjian (2018); Koran and Koran (2017); Shokouhi and Rezaei (2015); Al-Aghbari (2016); Mohammed (2012); Locastro (2012); Brubæk (2012); Aufa (2014); Rajabia, Azizifara, and Gowhary (2015); Rueda (2006); and Choraih, Loutfi, and Mansoor (2016) emphasized on teaching pragmatics in classrooms. They reached a decision that teaching English as a foreign and second language can be improved if it taught and learned through pragmatics. Accordingly, pragmatics should be part of teaching a language as it played a main role in developing learners' communicative ability. Thus, pragmatics enabled learners to interact appropriately in different contexts. The second section reviewed the articles that analyzed the pragmatic content in textbooks. Different results obtained from the articles. The cream of the 
cream is that not all the textbooks include pragmatic information. Thus, syllabus designers should pay more attention to pragmatics as they edit or design curricula for EFL learners. As for the researchers who concluded that textbooks have adequate pragmatic knowledge, they emphasized on modifying and re-editing more pragmatic information to include what is not investigated yet. They also emphasized that despite the percentage of pragmatic information found in the textbooks, still this percentage is inconvincible, it advised to adopt wider list of pragmatic information to develop learners' communicative ability through not only linguistic competence but also pragmatic competence respectively. Besides emphasizing on grammar aspects only, is not enough, thus, teachers should encourage learners to pay more attention to how to use language appropriately in different contexts and avoid making pragmatic mistakes to breakdown the communication. To help learners avoid making pragmatic mistake, it is necessary to teach them the sociocultural rules of the English. Pragmatic knowledge of a language is better acquired by more practicing in classrooms and more practice through various exercises and activities.

\section{References}

Al-Aghbari, D. (2016). Integrating pragmatic competence in teaching English to the students of medicine at Taiz University. Linguistics. Université de Strasbourg, 2016.

Al-Qazzaz, A. (2015). The Place of Pragmatics in English Language Teaching. AhlAlbait Journal. Vol. (7).

Arghashi, T. and Gorjian, B. (2018). The Impact of Teaching Pragmatic Functions to High School Learners. Journal of Applied Linguistics and Language Learning 2018, 4(3): 4958DOI: 10.5923/j.jall1.20180403.01

Aufa, F. (2014). The Use of Discourse Completion Task (DCT) as Explicit Instruction on Indonesian EFL Learners' Production of Suggestion Acts. International Journal on Studies in English Language and Literature. (IJSELL), 2(6), 1-10.

Bardovi-Harlig, K. (1999). Exploring the interlanguage of interlanguage pragmatics A research agenda for acquisitional pragmatics. Language learning, 49, 677-713.

Bardovi-Harlig, K., \& Hartford, B. (1996). Input in an institutional setting. Studies in Second Language Acquisition, 15, 279-304.

Bardovi-Harlig, K., Hartford, B.A.S., Mahan-Taylor, R., Morgan, M. J., \& Reynolds, D. W. (1991). Developing pragmatic awareness: Closing the conversation. ELT Journal, 45, 4-15.

Blum-Kulka, S., House, J., \& Kasper, G. (1989). Investigating Cross-cultural Pragmatics: An introductory overview. In Blum-Kulka, House \& Kasper (Eds). Cross-Cultural Pragmatics: Requests and Apologies. (pp. 1-34). New Jersey: Ablex Publishing Corporation.

Barron, A. (2003). Acquisition in interlanguage pragmatics: learning how to do things with words in a study abroad context. Amsterdaml Philadelphia: John Benjamins Publishing Company.

Blum-Kulka, House, \& Kasper. (Eds.). (1989). Cross-Cultural pragmatics: Requests and apologies. Norwood, U.: Ablex.

Boxer, D., \& Pickering, L. (1995). Problems in the presentation of speech acts in ELT materials: The case of complaints. ELT Journal, 49, 44-58.

Carrell, P. L. \& Konneker, B. H. (1981). Politeness: comparing native and non-native judgments. Language Learning, 31 (I), 17-30.

Celce-Murcia, M. (Ed.). (2001). Teaching English as a second or foreign language (3'd ed.). United States, Australia: Heinle and Heinle, Thomson Learning. 
Choraih, M., Loutfi, M., and Mansoor, A. (2016). The Importance of Pragmatic Competence in the EFL Curriculum: Application and Implications. Arab World English Journal, December 2016. ASELS Annual Conference Proceedings, 2016 Mohammed V University of Rabat, Morocco

Cook, H. (2001). Why can't learners of Japanese as a foreign language distinguish polite from impolite speech styles? In Kenneth R. Rose \& Gabriele Kasper (Eds.) Pragmatics in Language Teaching. (pp. 80-102).New York: Cambridge University Press.

Crystal, D. (1997). A dictionary of linguistics and phonetics. 4th edition. Cambridge, MA: Blackwell.

Ekin, T. Y. M. (2013). Do current EFL course books work for the development of L2 pragmatic competence? The case of suggestions. Procedia-Social and Behavioral Sciences, 93, 1306-1310.

Eslami-Rasekh, Z., Eslami-Rasekh, A., \& Fatahi, A. (2004). Using metapragmatic instruction to improve advanced EFL learners pragmatic awareness. TESL EJ, 8 (2) A2, 1-12.

Fatah, Y. and Ibrahim, N. (2020). The Importance of Utilizing Pragmatics in EFL/ESL Context. Asian-Pacific Journal of Second and Foreign Language Education

Ferrara, A. (1985). Pragmatics. In T. A. van Dijk (Ed.), Handbook of discourse analysis (Vol. 2, pp. 137-157). London: Academic Press.

Gilmore, A. (2004). A comparison of textbook and authentic interactions. ELTJournal, 58(4),363-374.

Huang, Y. (2007). Pragmatics. New York, NY: Oxford University Press.

Hyde, M. (1998). Intercultural competence in English language education. Modern English Teacher 7(2), 7-11.

Hymes, D.H. (1972). On communicative competence. In J.B.Pride \& J. Holmes (Eds.), Sociolinguistics (pp.269-293). Hannondsworth: Penguin.

Ji, P. (2007). Pragmatics and pedagogy: An examination of College English training in China (Unpublished doctoral thesis), University of Sydney, Australia.

Kasper, G. and Schmidt, R. (1996). Developmental issues in interlanguage pragmatics. Studies in Second Language Acquisition, 18, 149-169.

Kasper, G. (1997). Can pragmatic competence be taught? (Net Work 6) Honolulu: University of Hawaii, Second Language Teaching and Curriculum Center. www.nflrc.hawaii.edu/Net-Works/NW06/

Kasper, G., \& Rose, K. R. (1999). Pragmatics and second language acquisition. Annual review of Applied Linguistics, 19, 81- 104.

Kasper, G. (1997a). Can pragmatic competence be taught? (NetWork \#6) [HTML document]. Honolulu: University of Hawaii, Second Language Teaching \& Curriculum Center. Retrieved from the World Wide Web: http://www.nflrc.hawaii.edu/NetWorks/NW06/

Kasper, G. (2001). Classroom research on interlanguage pragmatics. In Kasper, G., \& Rose, K. (Eds.). Pragmatics and language teaching, (pp.33-60). Cambridge: Cambridge University Press.

Kasper, G. (1998). Interlanguage pragmatics. In H. Byrnes (Ed.), Learning foreign and second languages: Perspectives in research and scholarship. (pp. 183-208). New York: The modern language association of America.

Kasper, G., \& Rose, K. (2002). Pragmatic Development in a Second Language. Blackwell Publishing, Inc.

Kecskes, I., \& Romero-Trillo, J. (2013). Introduction. In I. Kecskes \& J. Romero-Trillo (Eds.), Research trends in intercultural pragmatics (pp. 1-3). Boston: Walter De Gruyter. 
Kim, D., \& Hall, 1. K. (2002). The role of an interactive book reading program in the development of second language pragmatic competence. The Modern Language Journal, 86(iii), 332-348.

Koran E. and Koran, S. (2017). Pragmatic Competence as an Integral Part of EFL Teaching. International Journal of Social Sciences \& Educational Studies ISSN 2520-0968 (Online), ISSN 2409-1294 (Print), December 2017, Vol.4, No.3

Lakoff, R. T. (1972). Language in context. Language, 48(4), 907-927.

Leech, G. (1983). Principles of pragmatics. London: Longman.

Levinson, S. (1983). Pragmatics. Cambridge: Cambridge University Press.

LoCastro, V. (I 997b). Politeness and pragmatic competence in foreign language education. Language Teaching Research, 1(3),239-267.

LoCastro, V. (2012). Defining the terriotery. In V. LoCastro , Pragmatics for language educators: A Sociolinuistic Perspective. pp.3-17. London: Routledge.

Mey, J.L. (2001). Pragmatics: an introduction. Oxford, Blackwell Publishers.

Mir, M. (1992). Do we all apologize the same? An empirical study of the act of apologizing by Spanish speakers learning English. In L. Bouton \& Kachru, Y. (Eds.). Pragmatics and language learning, monograph series vol. 3, 1-19. Urbana-Champaign: Division of English as an international language, University of Illinois, Urbana-Campaign.

Mohammed, M. (2012) Teach ability of Pragmatic Competence: The Impact of Explicit Instruction on the Development of Iraqi Freshmen EFL Learners' Pragmatic Competence. The Arab Gulf Journal, Vol. (40), Issue (1-2).

Morris, C. H. (1938). Foundation of the theory of signs. In O. Neurath (Ed.), International Encyclopedia of Unified Science (vol. 1) Chicago: University of Chicago Press.

Nguyen, T. T. M. (2011). Learning to communicate in a globalized world: To what extent do school textbooks facilitate the development of intercultural pragmatic competence? RELC Journal, 42(1), 17-30.

Rose, K. R., \& Kasper, G. (Eds.). (2001). Pragmatics in language teaching. Cambridge: Cambridge University Press.

Rose, K. R. (2005). On the effects of instruction in second language pragmatics. System, 33, 385-399.

Rose, K. R. (2000). An exploratory cross-sectional study of interlanguage pragmatic development. Studies in Second Language Acquisition, 22, 27-67.

Rueda, Y. T. (2006). Developing Pragmatic Competence in a Foreign Language. Colombian Applied Linguistics Journal, 169-182.

Schmidt, R. (2001). Attention. In P. Robinson (Ed.), Cognition and second language instruction (pp. 3-32). Cambridge: Cambridge University Press.

Tanaka, K. (1997). Developing pragmatic competence: a learners-as-researchers approach. TESOL Journal, 6(3), 14-18.

Thomas, J. (1995). Meaning in interaction: An introduction to pragmatics. London: Longman.

Shokouhi, S. and Rezaei, A. (2015). The Importance of Teaching Pragmatics in the Classrooms (Focus on Complimenting). Journal for the Study of English Linguistics, 2015, Vol. 3, No. 1

Thomas, J. (1983). Cross-cultural pragmatic failure. Applied Linguistics, 4(2), 91-112.

Vu, N. M. (2017). Teaching pragmatics in English as a Foreign Language at a Vietnamese university: Teachers' perceptions, curricular content, and classroom practices. University of Sydney. Doctoral Dissertation. Retrieved from https://ses.library.usyd.edu.au/handle/2123/16157 
Vellenga, H. (2004). Learning pragmatics from ESL \& EFL textbooks: How likely? TESLEJ, 8(2), 25-38. Retrieved March 28, 2005, from http://www.kyotosu.ac.jp/informationltesl-ej

Verschueren, J. (1999). Understanding pragmatics. London: Arnold.

Yule, G. (1996). Pragmatics. Oxford: Oxford University Press. 